\title{
HLA Immune Function Genes in Autism
}

\author{
Anthony R. Torres, ${ }^{1}$ Jonna B. Westover, ${ }^{1}$ and Allen J. Rosenspire ${ }^{2}$ \\ ${ }^{1}$ Center for Persons with Disabilities, Utah State University, 6804 Old Main Hill, Logan, UT 84322, USA \\ ${ }^{2}$ Department of Immunology and Microbiology, School of Medicine, Wayne State University, 221 Lande Building, Detroit, \\ MI 48201, USA
}

Correspondence should be addressed to Anthony R. Torres, anthony.torres@usu.edu

Received 10 October 2011; Accepted 11 November 2011

Academic Editor: Judy Van de Water

Copyright ( $) 2012$ Anthony R. Torres et al. This is an open access article distributed under the Creative Commons Attribution License, which permits unrestricted use, distribution, and reproduction in any medium, provided the original work is properly cited.

\begin{abstract}
The human leukocyte antigen (HLA) genes on chromosome 6 are instrumental in many innate and adaptive immune responses. The HLA genes/haplotypes can also be involved in immune dysfunction and autoimmune diseases. It is now becoming apparent that many of the non-antigen-presenting HLA genes make significant contributions to autoimmune diseases. Interestingly, it has been reported that autism subjects often have associations with HLA genes/haplotypes, suggesting an underlying dysregulation of the immune system mediated by HLA genes. Genetic studies have only succeeded in identifying autism-causing genes in a small number of subjects suggesting that the genome has not been adequately interrogated. Close examination of the HLA region in autism has been relatively ignored, largely due to extraordinary genetic complexity. It is our proposition that genetic polymorphisms in the HLA region, especially in the non-antigen-presenting regions, may be important in the etiology of autism in certain subjects.
\end{abstract}

\section{Autism}

Leo Kanner first described autism in 1943 [1] after finding 11 children with common symptoms of obsessiveness, stereotypy, and echolalia at Johns Hopkins University. Autism remained an esoteric disorder for several decades until physicians and parents connected these symptoms with an increasing number of patients. It is important to note that the diagnostic criteria have been modified over the years to include a broader category of symptoms, thus increasing the number of children diagnosed with the disorder, now referred to as Autism Spectrum Disorder (ASD) [2]. Currently, the Centers for Disease Control and Prevention (CDC) states that the incidence of ASD is 1 out of 110 children in the United States [3]. The severity of ASD varies greatly with the most severe forms, much like Kanner autism, displaying language regression, seizures, and lower IQ. Altevogt et al. [4] have suggested that autism, or more properly ASD, is not a single disorder, but a collection of similar disorders each with different characteristics and perhaps etiologies.

Even after several decades of research, there is much debate around the world on the etiology of ASD. It is clear that ASD results from abnormal brain development in either the prenatal period or infancy stage of life. Exposure to mercury, maternal viral infections, autoimmune disorders, and the inheritance of certain gene combinations have been implicated in the etiology. Unfortunately, none of these areas have given clear answers as to the etiology. Fortunately, psychologists have made significant strides in treating children and it appears the earlier behavioral treatment starts, the better the outcome. Nevertheless, medical researchers continue to search for the cause(s) of ASD. This paper discusses a possible role for the immune system, and in particular immune function genes in the human leukocyte antigen region (HLA), as a research area that should be more closely investigated.

\section{Infections}

One of the first areas of interest in the 1960s and 1970s was the search for an infectious agent that might be involved in the etiology of ASD [5]. During this time, there were many case reports in the literature that suggested an association between congenital rubella infection and resultant autistic behaviors. However, after decades of research no definite role 
for infectious agents in autism etiology has been confirmed. On the other hand, these endeavors have led to observations that perhaps the immune system was involved in autism, and evidence continues to mount that immune abnormalities are indeed associated with ASD.

\section{Familial Studies}

Studies indicating familial clustering and the increases of ASD in twins have been interpreted by many as an indication of genetic predisposition. Twin studies show the concordance rates of monozygotic twins at 36-96\%, whereas dizygotic twins are $0-24 \%$ concordant, resulting in an estimated heritability of autism at $>90 \%$ [6-8]. Additionally, family studies have shown autism to have familial aggregation with $3-8 \%$ of subsequently born siblings either being autistic or showing some form of pervasive developmental disorder (PDD) [9, 10]. This is a 3- to 8 -fold increase in risk for siblings over the general population. A more recent study gave an estimate of $18.7 \%$ sibling recurrence risk for ASD, a 20 -fold increase over the general population [11]. It is important to note, however, that family data should be looked at with great caution, as individuals living in the same household will have similar exposures to microorganisms and environmental chemicals. Taking this into account, a recent paper based on data from twin pairs estimates the genetic heritability for ASD to be $14-67 \%$ [12]. However, this idea is somewhat controversial as many in the research community continue to feel that the results from family studies are indicative of a strong genetic etiology $[13,14]$.

\section{Genetics}

Many of the early genetic studies involved the examination of microsatellites throughout the human genome in an attempt to find genomic regions that would associate with autism. Overall, this approach was not very fruitful and researchers quickly started to examine single-nucleotide polymorphisms (SNPs) as techniques advanced [15]. With this approach many researchers proposed that multiple candidate genes were associated with ASD. Unfortunately, studies proposing candidate genes were often contradictory and proved to be unreliable [15]. One of the most interesting genetic findings in ASD is the association of autism with the MET receptor tyrosine kinase gene located on chromosome 7q31 as MET signaling participates in gastrointestinal repair, immune function, neocortical, and cerebellar growth [16]. It is important to mention that the autism MET associations have been replicated by other research groups [17]. This autism association showed a relative risk of 2.27 which is much lower than the relative risk for HLA gene/allele associations discussed below.

It is very reasonable to believe that deletions or duplications of genetic regions, which can cause lower or higher levels of gene expression, could produce pathological phenotypes. Consequently, newer approaches examining copy number variation (CNV) and microarray analyses of 500,000 SNPs or more have been in vogue for several years in the study of ASD. These newer approaches have identified CNV mutation differences in genes involved in neuronal cell adhesion and ubiquitin degradation as being associated with ASD [18]; however, these results have yet to be replicated by other researchers.

The neurexin-1 gene has been associated with a variety of developmental disorders including ASD [19]. The neurexin1 gene (2p16.3) is one of the largest genes in the human genome with 24 exons in $1.1 \mathrm{Mb}$. With two independent promotors there can be over 1,000 neurexin isoforms generated from the 24 exons in different cells or tissue. Another gene of interest is the contactin-associated protein-like 2 (CNTNAP2) gene that was shown to be associated in Old-Order Amish subjects with intractable epilepsy and ASD [20]. Three other groups have now confirmed the involvement of CNTNAP2 in ASD [21-23].

Both the neurexin-1 and the CNTNAP2 genes are involved in synaptic function. Although these approaches have shown a strong association of certain genes with ASD, only a small percentage of subjects with ASD have these mutations. For example, the neurexin-1gene is found in only about $0.5 \%$ of autism cases and $0.2 \%$ of controls. The $90 \%$ missing inheritance may be largely due to marked genetic heterogeneity, suggesting that different ASD phenotypes should be examined separately [24-26]. Recent genetic research has also associated numerous immune function genes with autism [27-30]. A large study that examined SNP data from several genomewide scans on 3,130 subjects with schizophrenia found that the 5 most significant SNP markers are found across the HLA region [31]. It appears that some of missing inheritance, at least in schizophrenia, was uncovered in the HLA region and we suggest a similar finding will be confirmed/uncovered in autism.

\section{Immune Abnormalities in Autism}

It is no surprise to see immune gene associations in ASD, as numerous researchers have reported immune abnormalities in autism for over 20 years. It has become increasingly obvious that inflammatory processes are associated with autism. Blood levels of the inflammatory cytokines IL-6, INF- $\gamma$, and TNF- $\alpha$ were shown to be elevated in autistic individuals compared to controls [32, 33]. Later, seminal work by Vargas et al. [34] utilized direct morphological analysis and immunohistologic techniques to show an active neuroinflammatory process in the cerebral cortex, white matter, and in particular the cerebellum of ASD patients that was dependent on activation of microglia and astroglia. Cytokine profiling demonstrated that neuroinflammation was accompanied by upregulation of the macrophage chemoattractant protein (MCP-1) and TGF-beta in brain tissue, and that MCP-1 was also upregulated in cerebral spinal fluid [34]. More recent work has directly demonstrated that aside from blood, IL6 , TNF- $\alpha$, and INF- $\gamma$ are elevated in ASD brains, along with the other inflammatory cytokines GM-CSF and IL-8 [35]. Most recently, it has been reported that the important inflammatory-associated transcription factor, nuclear factor kappa-light-chain-enhancer of activated B cells (NF- $\kappa \mathrm{B})$ is 
TABLE 1: A list of proteins against which autoantibodies have been found in the serum of subjects with autism.

\begin{tabular}{lc}
\hline Protein & Reference \\
\hline Transglutaminase 2 & {$[39]$} \\
45 and 62 kDa proteins in cerebellum & {$[40,41]$} \\
Voltage dependent anion channel (VDAC) & {$[42]$} \\
Hexokinase-1 & {$[42]$} \\
Mitochondrial protein & {$[43]$} \\
Antimitochondrial DNA auto-antibodies & {$[43]$} \\
Nuclear proteins & {$[44]$} \\
52 kDa protein in hypothalamus and thalamus & {$[45]$} \\
$43-48$ kDa protein in the hypothalamus & {$[45]$} \\
Folate receptor & {$[46]$} \\
Brain-derived neuro trophic factor & {$[47]$} \\
HSP90 & {$[48]$} \\
Myelin basic protein (MBP) & {$[38,49]$} \\
Myelin-associated glycoprotein (MAG) & {$[50]$} \\
Myelin oligodendrocyte glycoprotein (MOG) & {$[50]$} \\
Neuron-axon filament protein & {$[51]$} \\
Glial fibrillary acidic protein & {$[51]$} \\
\hline
\end{tabular}

upregulated in both blood [36] and brain tissue [37] of autistic individuals. Other immune abnormalities such as autoantibodies started to be reported in 1993 [38] (Table 1).

Autoantibodies to myelin basic protein have been noted by at least a couple of researchers [38, 52]. An increase in autoantibody reactivity has been reported against other brain proteins in ASD including nerve growth factor [53], brain endothelium [54], cerebellar proteins [40], and serotonin 5-HT receptors [55] and transglutaminase-2, a protein important in synaptic stabilization [39]. Croonenberghs et al. [56] noted a significant increase in gamma globulin especially of the IgG2 and IgG4 subclasses in children with autism over a control population. Autoantibodies to several uncharacterized brain-specific proteins have been reported in the plasma of autistic individuals. In particular, western blot analysis has shown the presence of IgG autoantibodies targeting a protein of approximately $52 \mathrm{kDA}$ located in the hypothalamus and thalamus of adult brain [45]. Other autoantibodies targeting three brain proteins of $43-48 \mathrm{kDA}$ located in the hypothalamus have also been observed in the serum of autistic individuals [45]. Autoantibodies targeting cerebellar proteins of 45 and $62 \mathrm{kDA}$ have been associated with ASD [40]. These autoantibodies may be specific to cerebellar Golgi cells, which are GABAergic interneurons [41]. Autoantibodies reactive to human brain proteins in the 36-39 and $61 \mathrm{kDA}$ range have also been found in the sera of mothers of autistic children. [57, 58].

It is important to note that while autoantibodies associated with ASD may be biomarkers, they may not necessarily be pathologic in and of themselves. Central tolerance refers to the process whereby immature lymphocytes are negatively selected based on the ability of their antigen receptors (the $\mathrm{B}$ cell receptor or $\mathrm{BCR}$ for $\mathrm{B}$ cells and the T-cell receptor or TCR for T cells) to recognize self-antigens [59-61]. Until fairly recently, it was believed that most immature lymphocytes recognizing self-antigens (autoimmune repertoire) were normally neutralized by virtue of central tolerance before they could mature, and that peripheral tolerance would insure the removal of any self-reactive lymphocyte escaping central tolerance. Peripheral tolerance refers to the process whereby mature self-reactive lymphocytes which have escaped central tolerance are eliminated, largely by CD95-mediated apoptosis [62]. Thus responses to foreign antigens were viewed as normal, while anti-self responses were considered necessarily pathologic. However, with the realization that many self-reactive lymphocytes survive central and peripheral tolerance, this view has had to be modified [49]. Limited immune responses to self-antigens (autoimmunity) are now understood to be normal and not necessarily pathologic [63].

Upon stimulation of the system with a pathogen, cognate lymphocyte clones representative of the antiforeign repertoire normally expand and mature, providing a protective immune response. On the other hand, it is the expansion and maturation of those clones representative of the autoimmune repertoire that leads to autoimmune disease. In other words, the developing immune system can be characterized as balancing production between antiforeign (protective) and antiself (autoimmune) repertoires. While a beneficial function of naturally occurring, low level autoimmune antibodies, also referred to as natural antibodies (NAs), remains a matter of debate, it appears as if the repertoire of NA is reflective of the susceptibility to develop specific autoimmune diseases $[64,65]$. Because central tolerance of $\mathrm{T}$ cells depends to a large extent upon the strength of the TCR interaction with an autoantigen or an HLA class I or II complex [59], the NA repertoire will to a large extent depend upon the HLA haplotype, with some haplotypes favoring autoantibodies targeting one antigen over another. For instance, in the case of ASD we have found an association with low level antibody responses to tissue transglutaminase, and that this response appears linked to the HLA-DR3/DQ2 and DR7/DQ2 haplotypes [39]. It is likely that the other autoantibodies noted above as being associated with ASD may be linked to different haplotypes.

Aside from autoantibodies and altered cytokine levels there appear to be other immune abnormalities associated with ASD. It was noted that there were decreased numbers of T-lymphocytes and an altered ratio of suppressor $\mathrm{T}$ lymphocytes to helper T-lymphocytes $[66,67]$ and altered Tlymphocytes responses in children with autism [68]. Warren et al. [69] reported that subjects with autism had reduced NK cell killing in the standard K562 target cell cytotoxicity assay. This observation of decreased NK cell killing has been repeated by at least a couple of other research teams $[28,70]$. One research group [71] observed that monocyte counts and neopterin levels were increased in autistic children compared to gender and age-matched healthy controls suggesting that the immune system was overactivated in the ASD group. Another elegant set of experiments involved the stimulation of cultured monocytes with several toll-like-receptor (TLR) ligands. The monocytes from subjects with ASD had significant increases or decreases in proinflammatory cytokines 
TABLE 2: Genes and alleles in the HLA region.

\begin{tabular}{llll}
\hline HLA genes & Number & HLA alleles & Number \\
\hline HLA class I genes & 6 & HLA class I alleles & HLA class II alleles \\
HLA class II genes & 12 & HLA class I-like alleles \\
HLA class I-like genes & 2 & \\
Non-HLA genes & 112 & \\
\hline Total genes & 132 & \\
\hline HLA class I genes & A/B/C/E/F/G & \\
HLA class I-like genes & MICA/MICB & \\
HLA class II genes & DRA/DRB/DQ/DP/DM/DO & \\
\hline
\end{tabular}

depending on the particular TLR ligand added to the cell culture media [72].

One large-scale study found that the frequency of autoimmune disorders in the families with autistic children was found to be higher than in control subjects, especially mothers of autistic children [73]. Another group demonstrated that autoimmune diseases were increased significantly in families with ASD compared with those of healthy control subjects [74], suggesting a link between the disorders. Croen et al. [75] showed that maternal psoriasis diagnosed around the time of pregnancy is significantly associated with a subsequent diagnosis of autism in the child. Additionally, they showed a 2-fold increase in risk for a child having ASD if the mother was diagnosed and with asthma or allergies during pregnancy. An association between a family history of type 1 diabetes mellitus (T1DM) and infantile autism as well as a significant association between maternal histories of either rheumatoid arthritis (RA) or celiac disease and ASDs was noted by Atladóttir et al. [76].

\section{Autism HLA Genetics}

HLA is the name for the major histocompatibility complex (MHC) in humans and HLA and MHC are often used interchangeably in the literature. The HLA region on chromosome 6p21 (about $4 \times 10^{6} \mathrm{bp}$ ) is of major interest in basic research as well as medicine as genes/proteins in this region are involved in many biological processes such as histocompatibility, inflammation, ligands for immune cell receptors, and the complement cascade. The HLA region has 20 typical HLA genes and 112 nontypical HLA genes (Table 2) that are inherited together as frozen blocks of DNA called ancestral or extended haplotypes. Complete DNA sequences have been published for 8 of the more common ancestral haplotypes in an effort to expedite basic and disease research [77]. It should be mentioned that smaller haplotypes can also be constructed for genes that are linked. HLA genes also play a role in reproduction, pregnancy maintenance, mate selection, and even kin recognition $[78,79]$ and have been associated with over 100 diseases/disorders including autism. The proteins encoded by HLA genes are ligands, receptors, cytokines, signaling factors, heat shock proteins, transcription regulators, and so forth. Current research is increasingly demonstrating a role for HLA proteins in neural cell interactions, synaptic function, cerebral hemispheric specialization, central nervous system (CNS) development [80-84], and even neurological disorders [85]. The genes of the HLA region are shown in Figure 1. Shiina et al. $[86,87]$ have published two excellent reviews on the HLA super-locus. Not only is there extraordinary complexity in the HLA genes, there are extensive haplotype-related transcriptional differences [88]. It has been shown that genetic mechanisms outside of the non-antigen-binding HLA genes in the ancestral haplotype 8.1 (also referred to as COX) are associated with susceptibility to many autoimmune diseases [89]. It is our proposition that HLA genes/proteins should be more carefully examined due to increasing evidence of autoimmune type associations in autism.

\section{HLA Associations in ASD}

It was suggested over 30 years ago by Stubbs and Magenis [90] that the HLA region might be important in autism. Warren et al. [91] first reported that the HLA ancestral haplotype 44.1 (B44-SC30-DR4) was associated with autism with a relative risk of 7.9. That result was confirmed in a separate case/control population [92]. Interestingly, the individual components of AH 44.1 (A2-B44-SC30-DR4) include a deleted C4B gene and DR $\beta 1^{*} 0401$, both of which have been shown independently to be significantly associated with ASD [93, 94]. Examination with different genetic markers than those used by Warren suggested that certain HLA haplotypes are associated with autism in Sardinian and Italian families $[95,96]$.

Warren et al. [97] reported that the shared epitopebinding pocket $\left(\mathrm{DR} \beta 1^{*} 0401,{ }^{*} 0404\right.$, and $\left.{ }^{*} 0101\right)$ in the third hypervariable region of $D R \beta 1$ has a strong association with autism. A relative risk of 19.8 for autism was reported for subjects with one of the two extended HLA haplotypes. Both of these haplotypes have many allelic similarities especially the DR $\beta 1 * 0401$.

AH 44.1 (HLA-A2, Cw5, B44, Bf*S, C2*C, C4A3, C4BQ0, DR $\left.\beta 1 * 0401, \mathrm{DQB1}{ }^{*} 0301\right)$.

AH 62.1 (HLA-A2, Cw3, B15, Bf*S, C2*C, C4A3, C4B3, $\mathrm{DR} \beta 1 * 0401, \mathrm{DQB} 1 * 0302)$.

The shared epitope has been associated with several autoimmune diseases such as rheumatoid arthritis, psoriatic arthritis, and systemic lupus erythematosus [98]. Torres et al. [93] confirmed the association of the HLA-DR4 allele and also found that the DR13 and DR14 alleles occurred less 


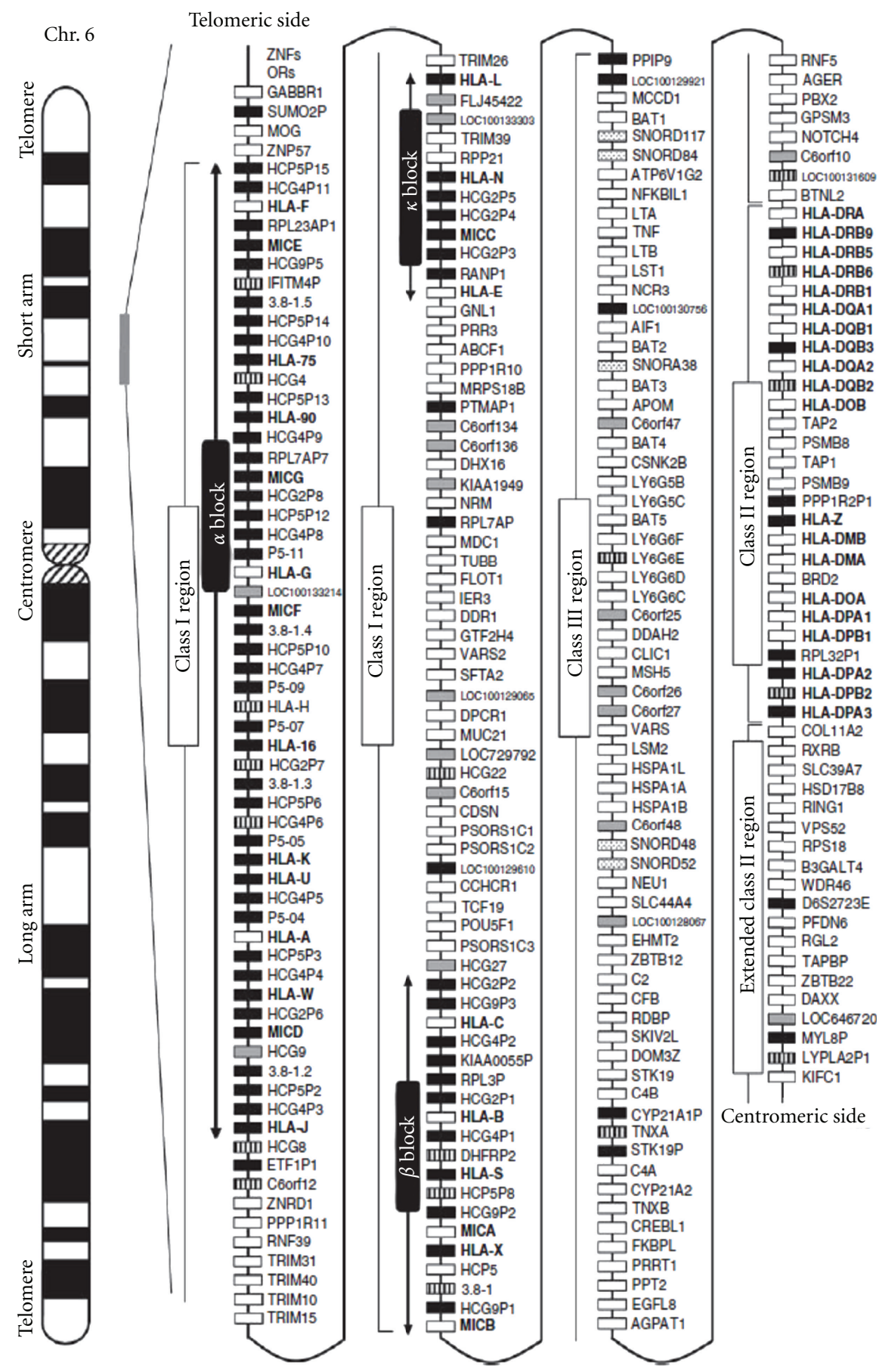

FIGURE 1: Gene map of the human leukocyte antigen (HLA) region. The major histocompatibility complex (MHC) gene map corresponds to the genomic coordinates of 29677984 (GABBR I) to 33485635 (KIFC1) in the human genome build 36.3 of the National Center for Biotechnology Information (NCBI) map viewer. The regions separated by arrows show the HLA subregions such as extended class I, classical class I, class III, classical class II, and extended class II regions from telomere (left and top side) to centromere (right and bottom side). White, gray, striped and black boxes show expressed genes, gene candidates, noncoding genes and pseudogenes, respectively. The location of the alpha, beta, and kappa blocks containing the cluster of duplicated HLA class I genes in the class I region are indicated. (Reprinted with permission from the Journal of Human Genetics [87].)

often in subjects with autism, suggesting a possible protective mechanism. Interestingly, the DR13 allele was inherited less frequently than expected from the mothers. Associations with autism and the DR4 allele have since been confirmed in three additional research groups. Lee et al. [99] demonstrated that boys with autism and their mothers had a significantly higher frequency of DR4 than normal control subjects (odds ratios 4.20 and 5.54, resp.), suggesting that a maternal-fetal 
immune interaction could be involved in autism. Johnson et al. [100] reported significant transmission disequilibrium for HLA-DR4 (odds ratio 4.67) from maternal grandparents to mothers of children with autism which also suggests a maternal-fetal interaction for HLA-DR4. It has been recently shown in Han Chinese that the HLA-DR $\beta 1$ allele frequencies including DR4 are different in subjects with autism versus control subjects [101].

It was reported 20 years ago that subjects with autism had a significant increase in the $\mathrm{C} 4 \mathrm{~B}$ null allele (C4B gene deletion) compared to control subjects [91]. After this observation, it was also noted that subjects with autism had a significant deficiency in the plasma C4B protein [102]. These initial findings of an increase in the deletion of the C4B gene was supported by examining a new population of subjects with autism [94]. Mostafa and Shehab [103] have recently reported a significant increase in the deletion of the C4B gene in the Egyptian population. They also reported an increased risk when there was a family history of autoimmune diseases in the autism population. Descriptions of several non-antigen-binding HLA genes that are associated with autoimmune diseases are discussed below and listed in Table 3.

\section{Non-Antigen-Binding HLA Genes in Class I}

Although MICA/MICB genes are structurally similar to classical antigen-binding HLA class I genes, they encode proteins that interact with different $\mathrm{T}$-cell receptors in response to stress as infection or neoplastic transformation. The two genes are located on the centromeric end of the class I region near HLA-B at the border of the class III region (Figure 1) [87]. MICA/MICB proteins are ligands for NKG2D receptors on NK cell and gamma/delta T-cell receptors. Adaptive immunity involves three lymphocyte populations (B cells, alpha/beta $\mathrm{T}$ cells, and gamma/delta $\mathrm{T}$ cells). Gam$\mathrm{ma} /$ delta $\mathrm{T}$ cells represent a small population of $\mathrm{T}$ cells that possess a T-cell receptor that is distinct from the typical alpha/beta T cell. They are concentrated in the intestinal mucosa and appear to have a prominent role in recognizing small bacterial phosphoantigens and undefined antigens presented by MICA/MICB proteins. Gamma/delta T cells have potent cytotoxic activity and have been considered a link between innate and adaptive immunity. Polymorphisms in MICA/MICB genes have been associated with T1DM, AD, and SLE independent of DR $\beta 1$ alleles. There are several genes associated with psoriasis (PSORSI locus). It is unclear how the risk is spread among these genes as they are closely linked. Two genes RNF39 and TRIM39 in the class I region have been associated with Behçet's disease.

\section{Non-Antigen-Binding HLA Genes in Class III}

Tumor necrosis factor-alpha (TNF- $\alpha$ ) is a proinflammatory, multifunctional cytokine that plays important roles in cell physiology. It is synthesized in numerous cells including macrophages, NK cells, T cells, mast cells, osteoblasts, granulocytes, smooth muscle cells, fibroblasts, and keratinocytes.
In the CNS, TNF- $\alpha$ is made in microglia cells, astrocytes, and neurons [141]. In the normal state, TNF- $\alpha$ drives acute and chronic inflammatory responses that leads to the removal of injurious stimuli and the restoration of homeostasis. TNF$\alpha$ is necessary for neural cell differentiation and neuron maturation and there is evidence that it is critical in the normal brain for proper synaptic function.

There is extensive research that implicates TNF- $\alpha$ as a key mediator in disease progression, inflammation, blood-brainbarrier deterioration, and even cell death [142]. Elevated levels are present in numerous neurological disorders including multiple sclerosis, Alzheimer's disease, Parkinson's disease, ischemia, traumatic brain injury, and as mentioned above, ASD [141]. It is unclear if TNF- $\alpha$ contributes to the disease state or the higher concentrations limit neuronal injury. There are three adjacent genes: lymphotoxin alpha and beta (LTA and LTB) and leukocyte-specific transcript-1 (LST1) in the TNF- $\alpha$ block. LTA and LTB are proinflammatory cytokines like TNF- $\alpha$, and LST1 plays a role in inflammatory and infectious diseases. It has been suggested that vaccineinduced immunity changes with certain haplotypes in these genes [143]. Two other genes important in immune function are adjacent to the TNF- $\alpha$ block. Nuclear factor of kappa light polypeptide gene enhancer in B-cells inhibitor-like 1(NF$\kappa \mathrm{BIL} 1)$ on the telomeric side of TNA- $\alpha$ is an inhibitor of NF$\kappa \mathrm{B}$, an important pleiotropic immune system transcription factor that is upregulated in ASD $[144,145]$. In addition, NF$\kappa$ BIL1 has been associated with several autoimmune diseases (Table 3). The natural cytotoxicity trigger receptor three (NCR3) gene on the centromeric side encodes proteins that are ligands for activating receptors on NK cells that recognize tumor cells [146]. Typical HLA-B and -C proteins are also ligands for KIR receptors on NK cells.

There are numerous heat shock proteins (HSPs), also referred to as chaperones, that assist the folding of newly synthesized proteins as well as those that have been unfolded or denatured [147]. HSPs are also important in cell protective functions and in inhibiting the apoptosis cascade. They are named by their molecular weights (HSP100, HSP90, HSP70, HSP60, and smaller HSPs). Although the proteins appear in normal cellular functions, they are induced to higher levels in trauma, epilepsy, neurodegenerative diseases, and other injuries. An underlying feature among AD, Parkinson's disease, spinocerebellar ataxia, and other neurodegenerative diseases is the accumulation of misfolded proteins and HSPs are being studied because of their role in folding and refolding proteins [147]. There is intense interest in HSPs as they appear to protect neurons [148] and one must remember that postmitotic neurons are unable to dilute misfolded or aggregated proteins through division.

There are three HSP70 genes (HSPA1L, HSPA1A, and HSPA1B) in the class III HLA region that are adjacent but separate genes. HSP70 proteins have been demonstrated to stimulate IL- 6 and TNF- $\alpha$ production, activate microglial cells, and stimulate phagocytosis [148]. HSP70 proteins are also important in autoimmunity by enhancing antigen presentation in both HLA class I and HLA class II systems [147, 149]. Peptides that are associated with HSP70 at the time of 
TABLE 3: Non-classical HLA genes associated with autoimmune diseases.

\begin{tabular}{|c|c|c|c|c|}
\hline & Gene & HGNC gene number & Autoimmune disease & References \\
\hline Extended class I & $\mathrm{OR} 2 \mathrm{H} 2$ & 8253 & SLE & {$[104]$} \\
\hline \multirow{5}{*}{ Class I } & RNF39 & 18064 & Behçet's disease & {$[105]$} \\
\hline & TRIM39 & 10065 & Behçet's disease & {$[105]$} \\
\hline & PSORS1 locus & 9573 & Systemic sclerosis, Psoriasis & {$[106-111]$} \\
\hline & MICA & 7090 & T1DM, AD, SLE & {$[112-114]$} \\
\hline & MICB & 7091 & SLE & {$[104]$} \\
\hline \multirow{11}{*}{ Class III } & BAT1-BAT5 & $13917-21$ & Alzheimer's, AIDS & {$[115,116]$} \\
\hline & NFKBIL1 & 7800 & Sjögren's syndrome, SLE, RA & {$[117,118]$} \\
\hline & TNF Block & 11892 & $\begin{array}{l}\text { Alzheimer's, Psoriasis, Autoimmune } \\
\text { hepatitis, Sarcoidosis }\end{array}$ & {$[115,119-121]$} \\
\hline & AIF1 & 352 & T1DM & {$[122]$} \\
\hline & HSP70 genes & $5232-4$ & MS & {$[123]$} \\
\hline & Complement genes & $1248,1324,1323$ & SLE, myasthenia gravis, T1DM & {$[124-126]$} \\
\hline & SKIV2L & 10898 & SLE & {$[127]$} \\
\hline & ATF6B (CREBL1) & 2349 & SLE & {$[104]$} \\
\hline & NOTCH4 & 7884 & Systemic sclerosis & {$[128]$} \\
\hline & C6orf10 & 13922 & SLE & {$[104]$} \\
\hline & BTNL2 & 1142 & Ulcerative colitis, Sarcoidosis & {$[129,130]$} \\
\hline \multirow{7}{*}{ Class II } & TAP2 & 44 & Psoriasis & {$[131]$} \\
\hline & PSMB8 & 9545 & Hypersensitivity pneumonitis & {$[132]$} \\
\hline & & & Psoriasis & {$[133]$} \\
\hline & TAP1 & 43 & Vitiligo & {$[134]$} \\
\hline & PSMB9 & 9546 & Psoriasis, Vitiligo & {$[133,134]$} \\
\hline & HLA-DM & 4934,4935 & $\begin{array}{l}\text { Psoriasis, Antiphospholipid } \\
\text { auto-antibodies, RA, SLE, T1DM }\end{array}$ & {$[131,135-138]$} \\
\hline & HLA-DO & 4936,4937 & common variable immunodeficiency & [139] \\
\hline \multirow{2}{*}{ Class II Extended } & HSD17B8 & 3554 & SLE & {$[104]$} \\
\hline & DAXX & 2681 & MS & {$[140]$} \\
\hline
\end{tabular}

Abbreviations: (HGNC) HUGO Gene Nomenclature Committee (http://www.genenames.org/); (SLE) systemic lupus erythematosus; (AIDS) acquired immune deficiency syndrome; (T1DM) type 1 diabetes mellitus; (AD) Addison's disease; (RA) rheumatoid arthritis; (MS) multiple sclerosis, PSORS1 psoriasis locus genes (CDSN, PSORS1C1, PSORS1C2, CCHCR1, POU5F1, PSORS1C3), TNF Block genes (LTA, TNF, LTB, LST1), HSP70 genes (HSPA1L, HSPA1A, HSPA1B), Complement genes (C2, C4B, C4A).

T-cell presentation have been shown to be more antigenic and therefore involved in autoimmunity [149, 150].

Another gene that is independently associated with autoimmune diseases outside of non-antigen-binding HLA alleles is allograft inflammatory factor-1 (AIF1). The SNP rs2269475 $\mathrm{C}>\mathrm{T}$ in AIF1 has been associated with RA. The $\mathrm{T}$ allele was significantly higher in the RA patients and there was no significant linkage disequilibria between the AIF1 SNP and DR $\beta 1$ alleles. Anticyclic citrullinated peptide antibodies commonly used to monitor RA were significantly increased in carriers with the $\mathrm{T}$ allele [151] but not the $\mathrm{C}$ allele.

\section{Non-Antigen-Binding HLA Genes in Class II}

Although HLA-DM and -DQ proteins have structures like classical antigen-binding HLA proteins, they work in the cytoplasm and not at the cell surface antigen-presenting
HLA proteins. DM stabilizes and edits the peptide repertoire presented by DQ proteins by catalyzing CLIP release. The associations of DQ2 with T1DM and celiac disease have been known for several decades; however, the biochemistry behind these associations has not been elucidated. It is now known that DQ2 is a poor substrate for DM and it has been proposed that antigen presentation in the thymus and periphery can be affected by impaired DQ-DM interactions so as to promote autoimmune disease [152]. HLA-DO is another nonclassical class II HLA protein that is involved in the loading of peptides to HLA-DR proteins by modulating the function of HLADM [153].

There are two genes in the class II region that encode proteins involved in the transport of antigen from the cytoplasm to the endoplasmic reticulum for binding to class I HLA proteins: transporter associated with antigen-processing 1 and 2 (TAP1 and TAP2). Several research groups have reported associations of TAP2 genes with SLE independent of classical HLA alleles [154]. This interaction is very interesting 
as it means that class II genes can affect class I antigen binding.

There are two other genes in the extended class II region that have been associated with autoimmune diseases (Table 3). Hydroxysteroid 17-beta dehydrogenase 8 (HSD17 $\beta 8$ ) is important in regulating the concentrations of active estrogens and androgens and high levels of estrogen are well known to be associated with SLE and other autoimmune diseases. The second gene, death-associated protein 6 (DAXX), is a very important protein that interacts with a variety of proteins in the nucleus and cytoplasm. Perhaps most importantly, it interacts with the death receptor Fas. Engstrom et al. [155] published a paper describing decreased expression of Fas on CD4 + T lymphocytes but higher serum levels of soluble Fas in ASD.

\section{Summary}

There is mounting evidence that the immune system plays a role in the pathogenesis of ASD in certain individuals. This evidence comes from several research areas including an increase in proinflammatory cytokines in blood and brain, autoantibodies to numerous antigens, and HLA associations.

Autism HLA associations have been observed across the entire HLA region. For example, in the class I region HLAA2 has been associated with autism by at least two research groups $[156,157]$. In the class II region several researchers have reported autism associations with the $\mathrm{DR} \beta 1^{*} 04$ allele $[93,99,100]$. Strong associations also appear in the class III region where the C4B null allele has been associated with autism with relative risks of 4.3 [94] and 4.6 [97], and an odds ratio of 6.3 [103]. The HLA-associated risk is the highest for autism (19.8) when combining two ancestral haplotypes (44.1 and 62.1). Both of these haplotypes have HLA-A 2 and DR $\beta 1^{*} 0401$ as well as other genetic similarities; however, these two alleles cannot account for all of the 19.8 risk. Compared to other genetic associations with autism, the HLA associations may be more important than realized, as they have the highest genetically associated risk, that we are aware of for autism. For example the MET gene, one of the most studies genetic regions in autism, has a relative risk of 2.27 [17].

It is our premise that some of the autism missing inheritance may be hidden in the HLA region, both in classical HLA alleles and nonclassical HLA genes, as seen in schizophrenia [31]. For example, the HLA class III region contains clusters of genes such as TNF- $\alpha$, HSP70, C4A/C4B, and NF- $\kappa$ BIL1 that are seminal in cellular function and are also associated with numerous autoimmune diseases (Table 3).

\section{Acknowledgment}

This report was supported in part by NIH Grant (RO1ES016669) and the Utah Autism Foundation (Salt Lake City, Utah).

\section{References}

[1] L. Kanner, "Autistic disturbances of affective contact," The Nervous Child, vol. 2, no. 2, pp. 217-250, 1943.

[2] F. R. Volkmar, M. State, and A. Klin, "Autism and autism spectrum disorders: diagnostic issues for the coming decade," Journal of Child Psychology and Psychiatry and Allied Disciplines, vol. 50, no. 1-2, pp. 108-115, 2009.

[3] Centers for Disease Control and Prevention (CDC), "Prevalence of autism spectrum disorders-Autism and developmental disabilities monitoring network, United States, 2006," CDC-Morbidity and Mortality Weekly Report, vol. 58, no. 10, pp. 1-20, 2009.

[4] B. M. Altevogt, S. L. Hanson, and A. I. Leshner, "Autism and the environment: challenges and opportunities for research," Pediatrics, vol. 121, no. 6, pp. 1225-1229, 2008.

[5] S. Chess, "Autism in children with congenital rubella," Journal of Autism and Childhood Schizophrenia, vol. 1, no. 1, pp. 33-47, 1971.

[6] S. Folstein and M. Rutter, "Infantile autism: a genetic study of 21 twin pairs," Journal of Child Psychology and Psychiatry and Allied Disciplines, vol. 18, no. 4, pp. 297-321, 1977.

[7] S. Steffenburg, C. Gillberg, L. Hellgren et al., "A twin study of autism in Denmark, Finland, Iceland, Norway and Sweden," Journal of Child Psychology and Psychiatry and Allied Disciplines, vol. 30, no. 3, pp. 405-416, 1989.

[8] A. Bailey, A. le Couteur, I. Gottesman et al., "Autism as a strongly genetic disorder: evidence from a British twin study," Psychological Medicine, vol. 25, no. 1, pp. 63-77, 1995.

[9] P. Bolton, H. Macdonald, A. Pickles et al., "A case-control family history study of autism," Journal of Child Psychology and Psychiatry and Allied Disciplines, vol. 35, no. 5, pp. 877900, 1994.

[10] E. R. Ritvo, L. B. Jorde, A. Mason-Brothers et al., "The UCLA-University of Utah epidemiologic survey of autism: recurrence risk estimates and genetic counseling," American Journal of Psychiatry, vol. 146, no. 8, pp. 1032-1036, 1989.

[11] S. Ozonoff, G. S. Young, A. Carter et al., "Recurrence risk for autism spectrum disorders: a baby siblings research consortium study," Pediatrics, vol. 128, no. 3, pp. e488-e495, 2011.

[12] J. Hallmayer, S. Cleveland, A. Torres et al., "Genetic heritability and shared environmental factors among twin pairs with autism," Archives of General Psychiatry, vol. 68, no. 11, pp. 1095-1102, 2011.

[13] C. M. Freitag, "The genetics of autistic disorders and its clinical relevance: a review of the literature," Molecular Psychiatry, vol. 12, no. 1, pp. 2-22, 2007.

[14] M. Rutter, "Genetic studies of autism: from the 1970s into the millennium," Journal of Abnormal Child Psychology, vol. 28, no. 1, pp. 3-14, 2000.

[15] M. W. State, "The genetics of child psychiatric disorders: focus on autism and tourette syndrome," Neuron, vol. 68, no. 2, pp. 254-269, 2010.

[16] D. B. Campbell, J. S. Sutcliffe, P. J. Ebert et al., "A genetic variant that disrupts MET transcription is associated with autism," Proceedings of the National Academy of Sciences of the United States of America, vol. 103, no. 45, pp. 16834-16839, 2006.

[17] M. C. Judson, K. L. Eagleson, and P. Levitt, "A new synaptic player leading to autism risk: met receptor tyrosine kinase," Journal of Neurodevelopmental Disorders, vol. 3, no. 3, pp. 282-292, 2011. 
[18] J. T. Glessner, K. Wang, G. Cai et al., "Autism genomewide copy number variation reveals ubiquitin and neuronal genes," Nature, vol. 459, no. 7246, pp. 569-573, 2009.

[19] M. S. Ching, Y. Shen, W. H. Tan et al., "Deletions of NRXN1 (neurexin-1) predispose to a wide spectrum of developmental disorders," American Journal of Medical Genetics B, vol. 153, no. 4, pp. 937-947, 2010.

[20] K. A. Strauss, E. G. Puffenberger, M. J. Huentelman et al., "Recessive symptomatic focal epilepsy and mutant contactinassociated protein-like 2," The New England Journal of Medicine, vol. 354, no. 13, pp. 1370-1377, 2006.

[21] M. Alarcón, B. S. Abrahams, J. L. Stone et al., "Linkage, association, and gene-expression analyses identify CNTNAP2 as an autism-susceptibility gene," American Journal of Human Genetics, vol. 82, no. 1, pp. 150-159, 2008.

[22] D. E. Arking, D. J. Cutler, C. W. Brune et al., "A common genetic variant in the neurexin superfamily member CNTNAP2 increases familial risk of autism," American Journal of Human Genetics, vol. 82, no. 1, pp. 160-164, 2008.

[23] B. Bakkaloglu, B. J. O'Roak, A. Louvi et al., "Molecular cytogenetic analysis and resequencing of contactin associated protein-like 2 in autism spectrum disorders," American Journal of Human Genetics, vol. 82, no. 1, pp. 165-173, 2008.

[24] T. A. Manolio, F. S. Collins, N. J. Cox et al., "Finding the missing heritability of complex diseases," Nature, vol. 461, no. 7265, pp. 747-753, 2009.

[25] D. B. Goldstein, "Common genetic variation and human traits," The New England Journal of Medicine, vol. 360, no. 17, pp. 1696-1698, 2009.

[26] J. McClellan and M. C. King, "Genetic heterogeneity in human disease," Cell, vol. 141, no. 2, pp. 210-217, 2010.

[27] J. P. Gregg, L. Lit, C. A. Baron et al., "Gene expression changes in children with autism," Genomics, vol. 91, no. 1, pp. 22-29, 2008.

[28] A. M. Enstrom, L. Lit, C. E. Onore et al., "Altered gene expression and function of peripheral blood natural killer cells in children with autism," Brain, Behavior, and Immunity, vol. 23, no. 1, pp. 124-133, 2009.

[29] J. T. Morgan, G. Chana, C. A. Pardo et al., "Microglial activation and increased microglial density observed in the dorsolateral prefrontal cortex in autism," Biological Psychiatry, vol. 68, no. 4, pp. 368-376, 2010.

[30] I. Voineagu, X. Wang, P. Johnston et al., "Transcriptomic analysis of autistic brain reveals convergent molecular pathology," Nature, vol. 474, no. 7351, pp. 380-384, 2011.

[31] H. Stefansson, R. A. Ophoff, S. Steinberg et al., "Common variants conferring risk of schizophrenia," Nature, vol. 460, no. 7256, pp. 744-747, 2009.

[32] J. Croonenberghs, E. Bosmans, D. Deboutte, G. Kenis, and M. Maes, "Activation of the inflammatory response system in autism," Neuropsychobiology, vol. 45, no. 1, pp. 1-6, 2002.

[33] P. Ashwood, P. Krakowiak, I. Hertz-Picciotto, R. Hansen, I. N. Pessah, and J. van de Water, "Associations of impaired behaviors with elevated plasma chemokines in autism spectrum disorders," Journal of Neuroimmunology, vol. 232, no. 1-2, pp. 196-199, 2011.

[34] D. L. Vargas, C. Nascimbene, C. Krishnan, A. W. Zimmerman, and C. A. Pardo, "Neuroglial activation and neuroinflammation in the brain of patients with autism," Annals of Neurology, vol. 57, no. 1, pp. 67-81, 2005.

[35] X. Li, A. Chauhan, A. M. Sheikh et al., "Elevated immune response in the brain of autistic patients," Journal of Neuroimmunology, vol. 207, no. 1-2, pp. 111-116, 2009.
[36] U. S. Naik, C. Gangadharan, K. Abbagani, B. Nagalla, N. Dasari, and S. K. Manna, "A study of nuclear transcription factor- $\kappa$ B in childhood autism," PLoS ONE, vol. 6, no. 5, p. e19488, 2011.

[37] A. M. Young, E. Campbell, S. Lynch, J. Suckling, and S. J. Powis, "Aberrant NF- $\kappa$ B expression in autism spectrum condition: a mechanism for neuroinflammation," Frontiers in Psychiatry, vol. 2, no. 27, pp. 1-8, 2011.

[38] V. K. Singh, R. P. Warren, J. D. Odell, W. L. Warren, and P. Cole, "Antibodies to myelin basic protein in children with autistic behavior," Brain, Behavior, and Immunity, vol. 7, no. 1, pp. 97-103, 1993.

[39] A. Rosenspire, W. Yoo, S. Menard, and A. R. Torres, "Autism spectrum disorders are associated with an elevated autoantibody response to tissue transglutaminase-2," Autism Research, vol. 4, no. 4, pp. 242-249, 2011.

[40] P. Goines, L. Haapanen, R. Boyce et al., "Autoantibodies to cerebellum in children with autism associate with behavior," Brain, Behavior, and Immunity, vol. 25, no. 3, pp. 514-523, 2011.

[41] S. Wills, C. C. Rossi, J. Bennett et al., "Further characterization of autoantibodies to GABAergic neurons in the central nervous system produced by a subset of children with autism," Molecular Autism, vol. 2, p. 5, 2011.

[42] M. Gonzalez-Gronow, M. Cuchacovich, R. Francos et al., "Antibodies against the voltage-dependent anion channel (VDAC) and its protective ligand hexokinase-I in children with autism," Journal of Neuroimmunology, vol. 227, no. 1-2, pp. 153-161, 2010.

[43] B. Zhang, A. Angelidou, K. D. Alysandratos et al., "Mitochondrial DNA and anti-mitochondrial antibodies in serum of autistic children," Journal of Neuroinflammation, vol. 7, p. 80, 2010.

[44] G. A. Mostafa and N. Kitchener, "Serum anti-nuclear antibodies as a marker of autoimmunity in Egyptian autistic children," Pediatric Neurology, vol. 40, no. 2, pp. 107-112, 2009.

[45] M. Cabanlit, S. Wills, P. Goines, P. Ashwood, and J. van de Water, "Brain-specific autoantibodies in the plasma of subjects with autistic spectrum disorder," Annals of the New York Academy of Sciences, vol. 1107, pp. 92-103, 2007.

[46] V. T. Ramaekers, N. Blau, J. M. Sequeira, M. C. Nassogne, and E. V. Quadros, "Folate receptor autoimmunity and cerebral folate deficiency in low-functioning autism with neurological deficits," Neuropediatrics, vol. 38, no. 6, pp. 276-281, 2007.

[47] A. M. Connolly, M. Chez, E. M. Streif et al., "Brain-derived neurotrophic factor and autoantibodies to neural antigens in sera of children with autistic spectrum disorders, LandauKleffner syndrome, and epilepsy," Biological Psychiatry, vol. 59, no. 4, pp. 354-363, 2006.

[48] M. Evers, C. Cunningham-Rundles, and E. Hollander, "Heat shock protein 90 antibodies in autism," Molecular Psychiatry, vol. 7, supplement 2, pp. S26-S28, 2002.

[49] C. M. Brickman and Y. Shoenfeld, "The mosaic of autoimmunity," Scandinavian Journal of Clinical and Laboratory Investigation, vol. 61, no. 235, pp. 3-15, 2001.

[50] A. Vojdani, A. W. Campbell, E. Anyanwu, A. Kashanian, K. Bock, and E. Vojdani, "Antibodies to neuron-specific antigens in children with autism: possible cross-reaction with encephalitogenic proteins from milk, Chlamydia pneumoniae and Streptococcus group A," Journal of Neuroimmunology, vol. 129, no. 1-2, pp. 168-177, 2002. 
[51] V. K. Singh, R. Warren, R. Averett, and M. Ghaziuddin, "Circulating autoantibodies to neuronal and glial filament proteins in autism," Pediatric Neurology, vol. 17, no. 1, pp. 88-90, 1997.

[52] H. Jyonouchi, S. Sun, and H. Le, "Proinflammatory and regulatory cytokine production associated with innate and adaptive immune responses in children with autism spectrum disorders and developmental regression," Journal of Neuroimmunology, vol. 120, no. 1-2, pp. 170-179, 2001.

[53] V. M. Bashina, I. A. Kozlova, and T. P. Kliushnik, "An elevation in the level of autoantibodies to nerve-growth factor in the blood serum of schizophrenic children," Zhurnal Nevrologii i Psikhiatrii Imeni S.S. Korsakova, vol. 97, no. 1, pp. 47-51, 1997.

[54] A. M. Connolly, M. G. Chez, A. Pestronk, S. T. Arnold, S. Mehta, and R. K. Deul, "Serum autoantibodies to brain in Landau-Kleffner variant, autism, and other neurologic disorders," The Journal of Pediatrics, vol. 134, no. 5, pp. 607613, 1999.

[55] R. D. Todd and R. D. Ciaranello, "Demonstration of interand intraspecies differences in serotonin binding sites by antibodies from an autistic child," Proceedings of the National Academy of Sciences of the United States of America, vol. 82, no. 2, pp. 612-616, 1985.

[56] J. Croonenberghs, A. Wauters, K. Devreese et al., "Increased serum albumin, $\gamma$ globulin, immunoglobulin IgG, and IgG2 and IgG4 in autism," Psychological Medicine, vol. 32, no. 8, pp. 1457-1463, 2002.

[57] H. S. Singer, C. M. Morris, C. D. Gause, P. K. Gillin, S. Crawford, and A. W. Zimmerman, "Antibodies against fetal brain in sera of mothers with autistic children," Journal of Neuroimmunology, vol. 194, no. 1-2, pp. 165-172, 2008.

[58] L. A. Croen, D. Braunschweig, L. Haapanen et al., "Maternal mid-pregnancy autoantibodies to fetal brain protein: the early markers for autism study," Biological Psychiatry, vol. 64, no. 7, pp. 583-588, 2008.

[59] K. A. Hogquist, T. A. Baldwin, and S. C. Jameson, "Central tolerance: learning self-control in the thymus," Nature Reviews Immunology, vol. 5, no. 10, pp. 772-782, 2005.

[60] J. Sprent, "Central tolerance of T cells," International Reviews of Immunology, vol. 13, no. 2, pp. 95-105, 1996.

[61] A. Basten, R. Brink, P. Peake et al., "Self tolerance in the B-cell repertoire," Immunological Reviews, no. 122, pp. 5-19, 1991.

[62] S. Baumann, A. Krueger, S. Kirchhoff, and P. H. Krammer, "Regulation of $\mathrm{T}$ cell apoptosis during the immune response," Current Molecular Medicine, vol. 2, no. 3, pp. 257272, 2002.

[63] Q. Leng and Z. Bentwich, "Beyond self and nonself: fuzzy recognition of the immune system," Scandinavian Journal of Immunology, vol. 56, no. 3, pp. 224-232, 2002.

[64] E. Meffre and J. E. Salmon, "Autoantibody selection and production in early human life," Journal of Clinical Investigation, vol. 117, no. 3, pp. 598-601, 2007.

[65] F. J. Quintana and H. L. Weiner, "Understanding natural and pathological autoimmunity," Journal of Neuroimmunology, vol. 174, no. 1-2, pp. 1-2, 2006.

[66] R. P. Warren, N. C. Margaretten, N. C. Pace, and A. Foster, "Immune abnormalities in patients with autism," Journal of Autism and Developmental Disorders, vol. 16, no. 2, pp. 189197, 1986.

[67] D. R. Denney, B. W. Frei, and G. R. Gaffney, "Lymphocyte subsets and interleukin-2 receptors in autistic children,"
Journal of Autism and Developmental Disorders, vol. 26, no. 1, pp. 87-97, 1996.

[68] P. Ashwood, P. Krakowiak, I. Hertz-Picciotto, R. Hansen, I. N. Pessah, and J. van de Water, "Altered T cell responses in children with autism," Brain, Behavior, and Immunity, vol. 25, no. 5, pp. 840-849, 2011.

[69] R. P. Warren, A. Foster, and N. C. Margaretten, "Reduced natural killer cell activity in autism," Journal of the American Academy of Child and Adolescent Psychiatry, vol. 26, no. 3, pp. 333-335, 1987.

[70] A. Vojdani, E. Mumper, D. Granpeesheh et al., "Low natural killer cell cytotoxic activity in autism: the role of glutathione, IL-2 and IL-15," Journal of Neuroimmunology, vol. 205, no. 1-2, pp. 148-154, 2008.

[71] T. L. Sweeten, D. J. Posey, and C. J. McDougle, "High blood monocyte counts and neopterin levels in children with autistic disorder," American Journal of Psychiatry, vol. 160, no. 9, pp. 1691-1693, 2003.

[72] A. M. Enstrom, C. E. Onore, J. A. van de Water, and P. Ashwood, "Differential monocyte responses to TLR ligands in children with autism spectrum disorders," Brain, Behavior, and Immunity, vol. 24, no. 1, pp. 64-71, 2010.

[73] A. M. Comi, A. W. Zimmerman, V. H. Frye, P. A. Law, and J. N. Peeden, "Familial clustering of autoimmune disorders and evaluation of medical risk factors in autism," Journal of Child Neurology, vol. 14, no. 6, pp. 388-394, 1999.

[74] T. L. Sweeten, S. L. Bowyer, D. J. Posey, G. M. Halberstadt, and C. J. McDougle, "Increased prevalence of familial autoimmunity in probands with pervasive developmental disorders," Pediatrics, vol. 112, no. 5, pp. e420-e424, 2003.

[75] L. A. Croen, J. K. Grether, C. K. Yoshida, R. Odouli, and J. V. van de Water, "Maternal autoimmune diseases, asthma and allergies, and childhood autism spectrum disorders: a casecontrol study," Archives of Pediatrics and Adolescent Medicine, vol. 159, no. 2, pp. 151-157, 2005.

[76] H. O. Atladóttir, M. G. Pedersen, P. Thorsen et al., "Association of family history of autoimmune diseases and autism spectrum disorders," Pediatrics, vol. 124, no. 2, pp. 687-694, 2009.

[77] R. Horton, R. Gibson, P. Coggill et al., "Variation analysis and gene annotation of eight MHC haplotypes: the MHC haplotype project," Immunogenetics, vol. 60, no. 1, pp. 1-18, 2008.

[78] L. A. Knapp, “The ABCs of MHC," Evolutionary Anthropology, vol. 14, no. 1, pp. 28-37, 2005.

[79] A. Ziegler, H. Kentenich, and B. Uchanska-Ziegler, "Female choice and the MHC," Trends in Immunology, vol. 26, no. 9, pp. 496-502, 2005.

[80] B. G. Xiao and H. Link, "Immune regulation within the central nervous system," Journal of the Neurological Sciences, vol. 157, no. 1, pp. 1-12, 1998.

[81] G. S. Huh, L. M. Boulanger, H. Du, P. A. Riquelme, T. M. Brotz, and C. J. Shatz, "Functional requirement for class I MHC in CNS development and plasticity," Science, vol. 290, no. 5499, pp. 2155-2159, 2000.

[82] L. M. Boulanger and C. J. Shatz, "Immune signalling in neural development, synaptic plasticity and disease," Nature Reviews Neuroscience, vol. 5, no. 7, pp. 521-531, 2004.

[83] S. Cullheim and S. Thams, "The microglial networks of the brain and their role in neuronal network plasticity after lesion," Brain Research Reviews, vol. 55, no. 1, pp. 89-96, 2007. 
[84] M. Ohtsuka, H. Inoko, J. K. Kulski, and S. Yoshimura, "Major histocompatibility complex (Mhc) class Ib gene duplications, organization and expression patterns in mouse strain C57BL/6," BMC Genomics, vol. 9, p. 178, 2008.

[85] S. L. Bailey, P. A. Carpentier, E. J. McMahon, W. S. Begolka, and S. D. Miller, "Innate and adaptive immune responses of the central nervous system," Critical Reviews in Immunology, vol. 26, no. 2, pp. 149-188, 2006.

[86] T. Shiina, H. Inoko, and J. K. Kulski, "An update of the HLA genomic region, locus information and disease associations," Tissue Antigens, vol. 64, no. 6, pp. 631-649, 2004.

[87] T. Shiina, K. Hosomichi, H. Inoko, and J. K. Kulski, "The HLA genomic loci map: expression, interaction, diversity and disease," Journal of Human Genetics, vol. 54, no. 1, pp. 15-39, 2009.

[88] C. Vandiedonck, M. S. Taylor, H. E. Lockstone et al., "Pervasive haplotypic variation in the spliceo-transcriptome of the human major histocompatibility complex," Genome Research, vol. 21, no. 7, pp. 1042-1054, 2011.

[89] G. Candore, I. C. Campagna, I. Cuppari, D. di Carlo, C. Mineo, and C. Caruso, "Genetic control of immune response in carriers of the 8.1 ancestral haplotype," Annals of the New York Academy of Sciences, vol. 1110, pp. 151-158, 2007.

[90] E. G. Stubbs and R. E. Magenis, "HLA and autism," Journal of Autism and Developmental Disorders, vol. 10, no. 1, pp. 1519, 1980.

[91] R. P. Warren, V. K. Singh, P. Cole et al., "Increased frequency of the null allele at the complement C4b locus in autism," Clinical and Experimental Immunology, vol. 83, no. 3, pp. 438-440, 1991.

[92] W. W. Daniels, R. P. Warren, J. D. Odell et al., "Increased frequency of the extended or ancestral haplotype B44-SC30DR4 in autism," Neuropsychobiology, vol. 32, no. 3, pp. 120123, 1995.

[93] A. R. Torres, A. Maciulis, E. G. Stubbs, A. Cutler, and D. Odell, "The transmission disequilibrium test suggests that HLA-DR4 and DR13 are linked to autism spectrum disorder," Human Immunology, vol. 63, no. 4, pp. 311-316, 2002.

[94] D. Odell, A. Maciulis, A. Cutler et al., "Confirmation of the association of the C4B null allelle in autism," Human Immunology, vol. 66, no. 2, pp. 140-145, 2005.

[95] F. R. Guerini, E. Bolognesi, S. Manca et al., "Familybased transmission analysis of HLA genetic markers in Sardinian children with autistic spectrum disorders," Human Immunology, vol. 70, no. 3, pp. 184-190, 2009.

[96] F. R. Guerini, E. Bolognesi, M. Chiappedi et al., "HLA polymorphisms in Italian children with autism spectrum disorders: results of a family based linkage study," Journal of Neuroimmunology, vol. 230, no. 1-2, pp. 135-142, 2011.

[97] R. P. Warren, J. D. Odell, W. L. Warren et al., "Strong association of the third hypervariable region of HLA-DR $\beta 1$ with autism," Journal of Neuroimmunology, vol. 67, no. 2, pp. 97-102, 1996.

[98] D. E. de Almeida, S. Ling, and J. Holoshitz, "New insights into the functional role of the rheumatoid arthritis shared epitope," FEBS Letters, vol. 585, no. 23, pp. 3619-3626, 2011.

[99] L. C. Lee, A. A. Zachary, M. S. Leffell et al., "HLA-DR4 in families with autism," Pediatric Neurology, vol. 35, no. 5, pp. 303-307, 2006.

[100] W. G. Johnson, S. Buyske, A. E. Mars et al., "HLA-DR4 as a risk allele for autism acting in mothers of probands possibly during pregnancy," Archives of Pediatrics and Adolescent Medicine, vol. 163, no. 6, pp. 542-546, 2009.

[101] Y. L. Chien, Y. Y. Wu, C. H. Chen et al., "Association of HLADRB1 alleles and neuropsychological function in autism," Psychiatric Genetics, vol. 22, no. 1, pp. 46-49, 2012.

[102] R. P. Warren, R. A. Burger, D. Odell, A. R. Torres, and W. L. Warren, "Decreased plasma concentrations of the C4B complement protein in autism," Archives of Pediatrics and Adolescent Medicine, vol. 148, no. 2, pp. 180-183, 1994.

[103] G. A. Mostafa and A. A. Shehab, "The link of C4B null allele to autism and to a family history of autoimmunity in Egyptian autistic children," Journal of Neuroimmunology, vol. 223, no. 1-2, pp. 115-119, 2010.

[104] L. F. Barcellos, S. L. May, P. P. Ramsay et al., "High-density SNP screening of the major histocompatibility complex in systemic lupus erythematosus demonstrates strong evidence for independent susceptibility regions," PLoS Genetics, vol. 5, no. 10, Article ID e1000696, 2009.

[105] R. Kurata, H. Nakaoka, A. Tajima et al., “TRIM39 and RNF39 are associated with Behçet's disease independently of HLA$\mathrm{B} * 51$ and $-\mathrm{A} * 26$," Biochemical and Biophysical Research Communications, vol. 401, no. 4, pp. 533-537, 2010.

[106] Y. Allanore, M. Saad, P. Dieudé et al., "Genome-wide scan identifies TNIP1, PSORS1C1, and RHOB as novel risk loci for systemic sclerosis," PLoS Genetics, vol. 7, no. 7, Article ID e1002091, 2011.

[107] S. Gonzalez, J. Martinez-Borra, J. S. del Río et al., “The OTF3 gene polymorphism confers susceptibility to psoriasis independent of the association of HLA-Cw $* 0602$," Journal of Investigative Dermatology, vol. 115, no. 5, pp. 824-828, 2000.

[108] K. Asumalahti, C. Veal, T. Laitinen et al., "Coding haplotype analysis supports HCR as the putative susceptibility gene for psoriasis at the MHC PSORS1 locus," Human Molecular Genetics, vol. 11, no. 5, pp. 589-597, 2002.

[109] S. J. Holm, L. M. Carlén, L. Mallbris, M. Ståhle-Bäckdahl, and K. P. O'Brien, "Polymorphisms in the SEEK1 and SPR1 genes on $6 \mathrm{p} 21.3$ associate with psoriasis in the Swedish population," Experimental Dermatology, vol. 12, no. 4, pp. 435-444, 2003.

[110] S. J. Holm, F. Sánchez, L. M. Carlén, L. Mallbris, M. Ståhle, and K. P. O'Brien, "HLA-Cw*0602 associates more strongly to psoriasis in the Swedish population than variants of the novel 6p21.3 gene PSORS1C3," Acta Dermato-Venereologica, vol. 85, no. 1, pp. 2-8, 2005.

[111] S. Orrù, E. Giuressi, C. Carcassi, M. Casula, and L. Contu, "Mapping of the major psoriasis-susceptibility locus (PSORS1) in a 70-Kb interval around the corneodesmosin gene (CDSN)," American Journal of Human Genetics, vol. 76, no. 1, pp. 164-171, 2005.

[112] G. Gambelunghe, A. Brozzetti, M. Ghaderi, P. Candeloro, C. Tortoioli, and A. Falorni, "MICA gene polymorphism in the pathogenesis of type 1 diabetes," Annals of the New York Academy of Sciences, vol. 1110, pp. 92-98, 2007.

[113] A. Falorni, A. Brozzetti, D. L. Torre, C. Tortoioli, and G. Gambelunghe, "Association of genetic polymorphisms and autoimmune Addison's disease," Expert Review of Clinical Immunology, vol. 4, no. 4, pp. 441-456, 2008.

[114] G. Gambelunghe, R. Gerli, E. B. Bocci et al., "Contribution of MHC class I chain-related A (MICA) gene polymorphism to genetic susceptibility for systemic lupus erythematosus," Rheumatology, vol. 44, no. 3, pp. 287-292, 2005.

[115] A. Gnjec, K. L. D’Costa, S. M. Laws et al., "Association of alleles carried at TNFA -850 and BAT1 -22 with Alzheimer's disease," Journal of Neuroinflammation, vol. 5, p. 36, 2008. 
[116] S. Limou, S. le Clerc, C. Coulonges et al., "Genomewide association study of an AIDS-nonprogression cohort emphasizes the role played by HLA genes (ANRS genomewide association study 02)," Journal of Infectious Diseases, vol. 199, no. 3, pp. 419-426, 2009.

[117] J. Castiblanco and J. M. Anaya, "The I $\kappa$ BL gene polymorphism influences risk of acquiring systemic lupus erythematosus and Sjögren's syndrome," Human Immunology, vol. 69, no. 1, pp. 45-51, 2008.

[118] G. Tamiya, M. Shinya, T. Imanishi et al., "Whole genome association study of rheumatoid arthritis using 27039 microsatellites," Human Molecular Genetics, vol. 14, no. 16, pp. 2305-2321, 2005.

[119] K. Reich, U. Hüffmeier, I. R. König et al., "TNF polymorphisms in psoriasis: association of psoriatic arthritis with the promoter polymorphism TNF*-857 independent of the PSORS1 risk allele," Arthritis and Rheumatism, vol. 56, no. 6, pp. 2056-2064, 2007.

[120] L. C. Oliveira, G. Porta, M. L. C. Marin, P. L. Bittencourt, J. Kalil, and A. C. Goldberg, "Autoimmune hepatitis, HLA and extended haplotypes," Autoimmunity Reviews, vol. 10, no. 4, pp. 189-193, 2011.

[121] R. Kieszko, P. Krawczyk, S. Chocholska, A. Dmoszyńska, and J. Milanowski, "TNF- $\alpha$ and TNF- $\beta$ gene polymorphisms in Polish patients with sarcoidosis. Connection with the susceptibility and prognosis," Sarcoidosis Vasculitis and Diffuse Lung Diseases, vol. 27, no. 2, pp. 131-137, 2010.

[122] M. C. Eike, M. Olsson, D. E. Undlien et al., "Genetic variants of the HLA-A, HLA-B and AIF1 loci show independent associations with type 1 diabetes in Norwegian families," Genes and Immunity, vol. 10, no. 2, pp. 141-150, 2009.

[123] H. Cwiklinska, M. P. Mycko, B. Szymanska, M. Matysiak, and K. W. Selmaj, "Aberrant stress-induced Hsp70 expression in immune cells in multiple sclerosis," Journal of Neuroscience Research, vol. 88, no. 14, pp. 3102-3110, 2010.

[124] M. C. Pickering and M. J. Walport, "Links between complement abnormalities and systemic lupus erythematosus," Rheumatology, vol. 39, no. 2, pp. 133-141, 2000.

[125] D. Franciotta, M. Cuccia, E. Dondi, G. Piccolo, and V. Cosi, "Polymorphic markers in MHC class II/III region: a study on Italian patients with myasthenia gravis," Journal of the Neurological Sciences, vol. 190, no. 1-2, pp. 11-16, 2001.

[126] F. Jenhani, R. Bardi, Y. Gorgi, K. Ayed, and M. Jeddi, "C4 polymorphism in multiplex families with insulin dependent diabetes in the Tunisian population: standard C4 typing methods and RFLP analysis," Journal of Autoimmunity, vol. 5, no. 2, pp. 149-160, 1992.

[127] M. M. Fernando, C. R. Stevens, P. C. Sabeti et al., "Identification of two independent risk factors for lupus within the MHC in United Kingdom families," PLoS Genetics, vol. 3, no. 11, p. e192, 2007.

[128] O. Gorlova, J. E. Martin, B. Rueda et al., "Identification of novel genetic markers associated with clinical phenotypes of systemic sclerosis through a genome-wide association strategy," PLoS Genetics, vol. 7, no. 7, Article ID e1002178, 2011.

[129] S. Pathan, R. E. Gowdy, R. Cooney et al., "Confirmation of the novel association at the BTNL2 locus with ulcerative colitis," Tissue Antigens, vol. 74, no. 4, pp. 322-329, 2009.

[130] N. Milman, C. B. Svendsen, F. C. Nielsen, and T. V. O. Hansen, "The BTNL2 A allele variant is frequent in Danish patients with sarcoidosis," Clinical Respiratory Journal, vol. 5, no. 2 , pp. 105-111, 2011.

[131] C. W. Pyo, S. S. Hur, Y. K. Kim, T. Y. Kim, and T. G. Kim, "Association of TAP and HLA-DM genes with psoriasis in Koreans," Journal of Investigative Dermatology, vol. 120, no. 4, pp. 616-622, 2003.

[132] Á. Camarena, A. Aquino-Galvez, R. Falfán-Valencia et al., "PSMB8 (LMP7) but not PSMB9 (LMP2) gene polymorphisms are associated to pigeon breeder's hypersensitivity pneumonitis," Respiratory Medicine, vol. 104, no. 6, pp. 889894, 2010.

[133] U. Krämer, T. Illig, T. Grune, J. Krutmann, and C. Esser, "Strong associations of psoriasis with antigen processing LMP and transport genes TAP differ by gender and phenotype," Genes and Immunity, vol. 8, no. 6, pp. 513-517, 2007.

[134] C. B. Casp, J. X. She, and W. T. McCormack, "Genes of the LMP/TAP cluster are associated with the human autoimmune disease vitiligo," Genes and Immunity, vol. 4, no. 7, pp. 492-499, 2003.

[135] M. L. Sanchez, K. Katsumata, T. Atsumi et al., "Association of HLA-DM polymorphism with the production of antiphospholipid antibodies," Annals of the Rheumatic Diseases, vol. 63, no. 12, pp. 1645-1648, 2004.

[136] J. Morel, F. Roch-Bras, N. Molinari, J. Sany, J. F. Eliaou, and B. Combe, "HLA-DMA*0103 and HLA-DMB*0104 alleles as novel prognostic factors in rheumatoid arthritis," Annals of the Rheumatic Diseases, vol. 63, no. 12, pp. 1581-1586, 2004.

[137] J. Morel, C. S. Cda, O. Avinens, J. Sany, B. Combe, and J. F. Eliaou, "Polymorphism of HLA-DMA and DMB alleles in patients with systemic lupus erythematosus," Journal of Rheumatology, vol. 30, no. 7, pp. 1485-1490, 2003.

[138] Y. M. Sang, C. Yan, C. Zhu, G. C. Ni, and Y. M. Hu, "Association of human leukocyte antigen non-classical genes with type 1 diabetes," Chinese Journal of Pediatrics, vol. 41, no. 4, pp. 260-263, 2003.

[139] X. Chen and P. E. Jensen, "MHC class II antigen presentation and immunological abnormalities due to deficiency of MHC class II and its associated genes," Experimental and Molecular Pathology, vol. 85, no. 1, pp. 40-44, 2008.

[140] J. I. Satoh, M. Nakanishi, F. Koike et al., "Microarray analysis identifies an aberrant expression of apoptosis and DNA damage-regulatory genes in multiple sclerosis," Neurobiology of Disease, vol. 18, no. 3, pp. 537-550, 2005.

[141] S. L. Montgomery and W. J. Bowers, "Tumor necrosis factor$\alpha$ and the roles it plays in homeostatic and degenerative processes within the central nervous system," Journal of Neuroimmune Pharmacology. In press.

[142] M. K. McCoy and M. G. Tansey, "TNF signaling inhibition in the CNS: implications for normal brain function and neurodegenerative disease," Journal of Neuroinflammation, vol. 5, article 45, 2008.

[143] I. G. Ovsyannikova, R. A. Vierkant, V. S. Pankratz, R. M. Jacobson, and G. A. Poland, "Extended LTA, TNF, LST1 and hla gene haplotypes and their association with rubella vaccine-induced immunity," PLOS ONE, vol. 5, no. 7, Article ID e11806, 2010.

[144] U. S. Naik, C. Gangadharan, K. Abbagani, B. Nagalla, N. Dasari, and S. K. Manna, "A study of nuclear transcription factor- $\kappa$ B in childhood autism," PLoS ONE, vol. 6, no. 5, Article ID e19488, 2011.

[145] A. M. Young, E. Campbell, S. Lynch, J. Suckling, and S. J. Powis, "Aberrant NF- $\kappa$ B expression in autism spectrum condition: a mechanism for neuroinflammation," Front Psychiatry, vol. 2, no. 27, pp. 1-8, 2011. 
[146] C. E. Foster, M. Colonna, and P. D. Sun, "Crystal structure of the human natural killer (NK) cell activating receptor NKp46 reveals structural relationship to other leukocyte receptor complex immunoreceptors," Journal of Biological Chemistry, vol. 278, no. 46, pp. 46081-46086, 2003.

[147] G. Turturici, G. Sconzo, and F. Geraci, "Hsp70 and its molecular role in nervous system diseases," Biochemistry Research International, vol. 2011, Article ID 618127, 18 pages, 2011.

[148] J. I. Kakimura, Y. Kitamura, K. Takata et al., "Microglial activation and amyloid- $\beta$ clearance induced by exogenous heat-shock proteins," The FASEB Journal, vol. 16, no. 6, pp. 601-603, 2002.

[149] M. P. Mycko, H. Cwiklinska, A. Walczak, C. Libert, C. S. Raine, and K. W. Selmaj, "A heat shock protein gene (Hsp70.1) is critically involved in the generation of the immune response to myelin antigen," European Journal of Immunology, vol. 38, no. 7, pp. 1999-2013, 2008.

[150] D. G. Millar, K. M. Garza, B. Odermatt et al., "Hsp70 promotes antigen-presenting cell function and converts $\mathrm{T}$ cell tolerance to autoimmunity in vivo," Nature Medicine, vol. 9, no. 12, pp. 1469-1476, 2003.

[151] A. Pawlik, M. Kurzawski, T. Szczepanik et al., "Association of allograft inflammatory factor-1 gene polymorphism with rheumatoid arthritis," Tissue Antigens, vol. 72, no. 2, pp. 171175, 2008.

[152] T. Hou, H. Macmillan, Z. Chen et al., "An insertion mutant in DQA ${ }^{*} 0501$ restore susceptibility to HLA-DM: implications for disease associations," Journal of Immunology, vol. 187, no. 5, pp. 2442-2452, 2011.

[153] F. Deshaies, D. A. Diallo, J. S. Fortin et al., "Evidence for a human leucocyte antigen-DM-induced structural change in human leucocyte antigen-DO $\beta$," Immunology, vol. 127, no. 3, pp. 408-417, 2009.

[154] P. S. Ramos, C. D. Langefeld, L. A. Bera, P. M. Gaffney, J. A. Noble, and K. L. Moser, "Variation in the ATP-binding cassette transporter 2 gene is a separate risk factor for systemic lupus erythematosus within the MHC," Genes and Immunity, vol. 10, no. 4, pp. 350-355, 2009.

[155] H. A. Engstrom, S. Ohlson, E. G. Stubbs et al., "Decreased expression of CD95 (FAS/APO-1) on CD4+ T-lymphocytes from participants with autism," Journal of Developmental and Physical Disabilities, vol. 15, no. 2, pp. 155-163, 2003.

[156] P. Ferrante, M. Saresella, F. R. Guerini, M. Marzorati, M. C. Musetti, and A. G. Cazzullo, "Significant association of HLA A2-DR11 with CD4 naive decrease in autistic children," Biomedicine and Pharmacotherapy, vol. 57, no. 8, pp. 372374, 2003.

[157] A. R. Torres, T. L. Sweeten, A. Cutler et al., "The association and linkage of the HLA-A2 class I allele with autism," Human Immunology, vol. 67, no. 4-5, pp. 346-351, 2006. 


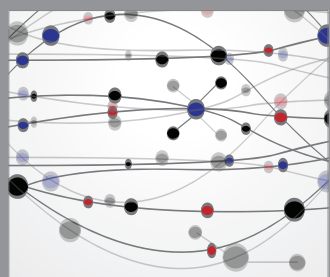

The Scientific World Journal
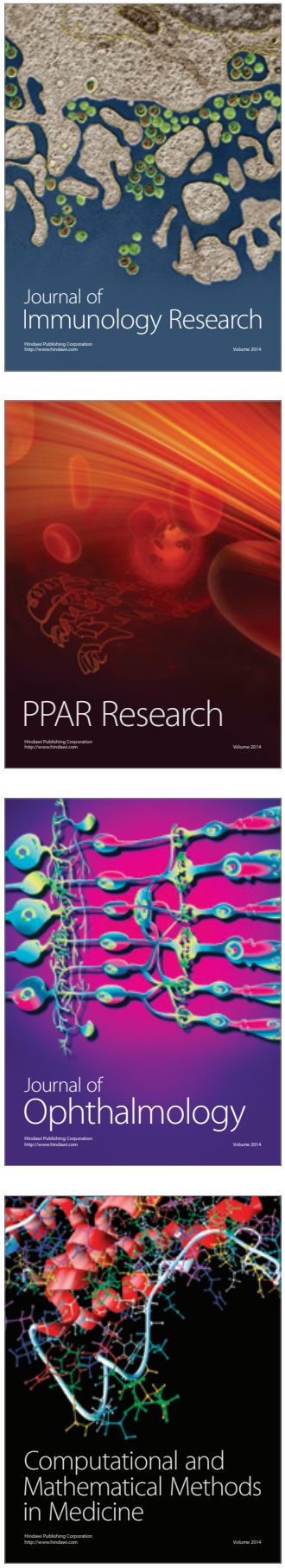

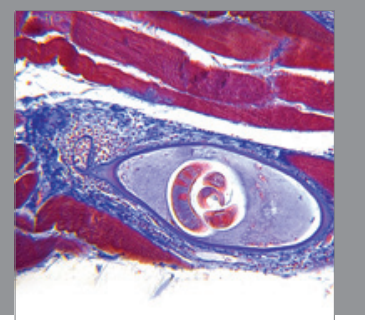

Gastroenterology

Research and Practice
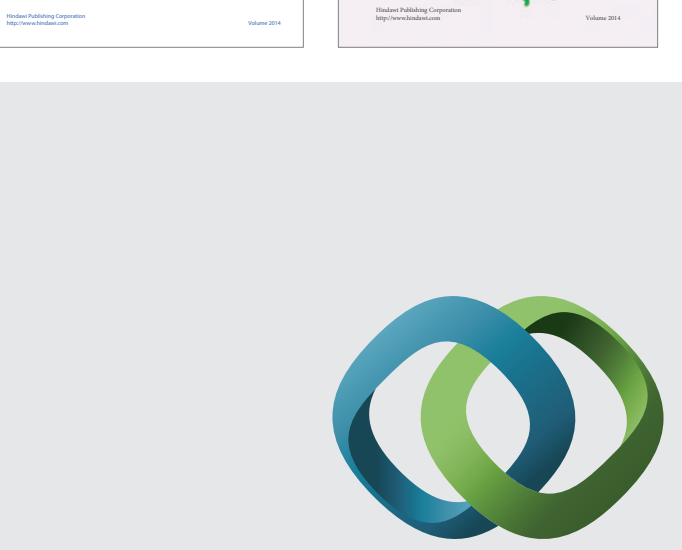

\section{Hindawi}

Submit your manuscripts at

http://www.hindawi.com
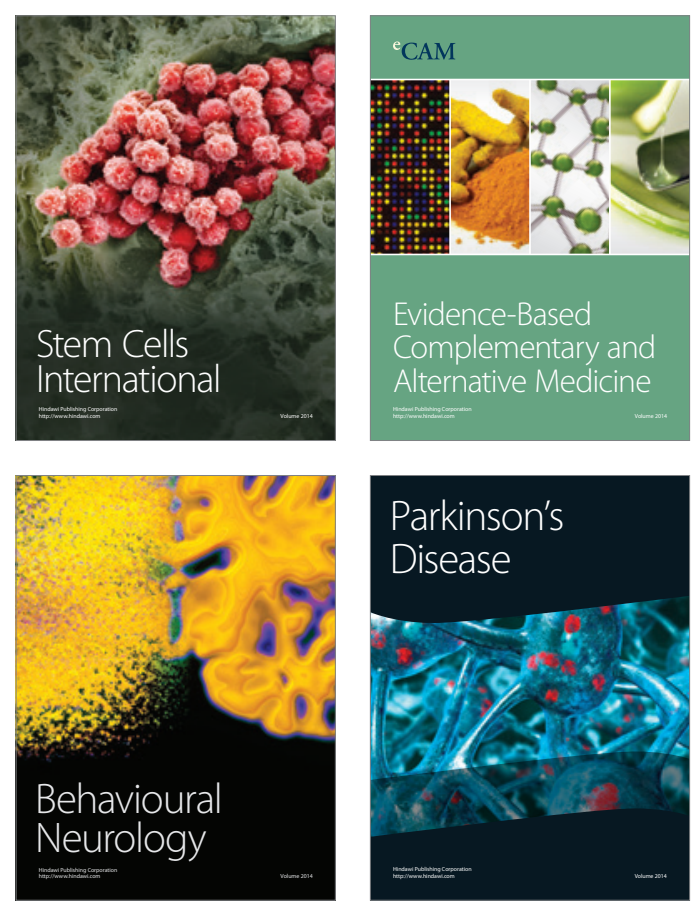

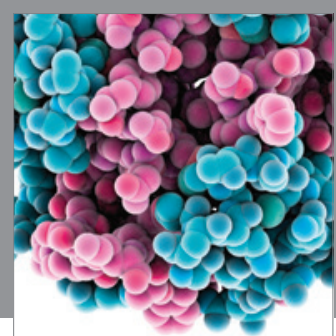

Journal of
Diabetes Research

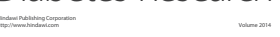

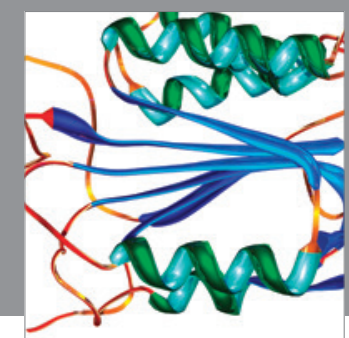

Disease Markers
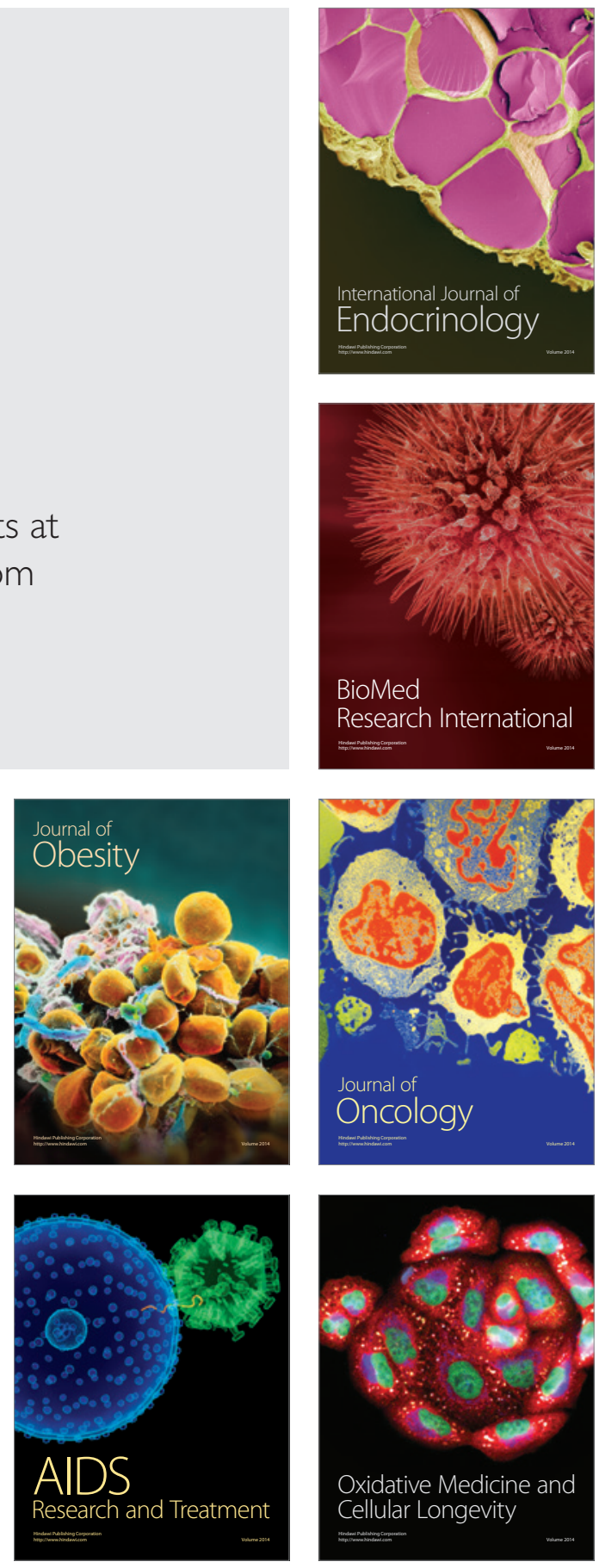